-measuring more than a foot in diameter at the top, and about $3 \mathrm{ft}$. in diameter at the base. If we accept reports which date back many years, a record height of more than $400 \mathrm{ft}$. has been claimed for these trees. Such a tree would top the cross on St. Paul's Cathedral by $35 \mathrm{ft}$.

It would be impossible to overrate the importance of this wood in the exceptional and unexpected demand created by the present War, the figures of production of which amaze and frighten the imagination. When we reflect upon the steady and overwhelming destruction of the timber resources of the world, and the requirements of future generations, we almost wonder how civilization can survive.

Hitherto insufficient efforts have been made to establish Douglas fir trees (Pseudotsuga Douglasii and Ps. taxifolia) in large quantities in Great Britain. The tree was introduced by William Douglas in 1827 , but although occasional efforts were made to plant on a large scale, their prominence and successful production to-day is largely due to proprietors such as the owners of Lythe Hill, Surrey, Murthly Castle, Taymount, Scotland, and Powerscourt, Ireland. Although in some areas success has been achieved, it is only during the last fifty years that attempts have been made to plant this tree for its useful qualities. While it does not thrive in some situations and on certain soils, we have evidence of the marvellous growth to which it can attain in a very short period. About seventy years ago a considerable area was planted with Douglas fir at Lythe Hill by Mr. Bicknell, then forester to the owner. On this same estate many other Douglas firs, in their rather tragic and shortened lifetime, reached a height of 100 feet and more. On the crest of the hill, and placed in such a position that it commanded a view of the whole forest, was an immense tree, known to those who frequented the site as "the monarch tree". It was also one of those planted by Mr. Bicknell about seventy years ago, an unusual specimen of white spruce (Abies sp., possibly grandis). It is not often that a man can plant a tree and during his lifetime actually see it reach a height of about $125 \mathrm{ft}$., with a straight bole moderately clear of branches to a length of $66 \mathrm{ft}$., with three leaders, bringing the full length of the bole to about $100 \mathrm{ft}$., and yet $\mathrm{Mr}$. Bicknell had this satisfaction before he died in 1941 . In all its glory the tree has unfortunately been felled. It contains $544 \mathrm{cub}$. ft. of useful timber, and as growing must have weighed about twenty tons.

It is worthy of notice that the original planter must have been actuated by a diligence and enthusiasm unknown since the time of John Evelyn, as there flourishes on the estate, side by side with the Douglas firs, a great number of unusual American trees, including Sequoia sempervirens, Wellingtonia gigantia, at least two sorts of maple, many Thuya, Cupressus, hemlock, juniper, Cryptomeria japonica, etc. The Sequoia also would seem to have found conditions favourable to its growth, since it has reached a great height and girth.

A magnificent Douglas fir can be seen at Powerscourt, Co. Wicklow, Ireland, planted by the present Viscount's father between 1865 and 1870 . This tree measures to-day $130 \mathrm{ft}$. in height, with a girth of $14 \mathrm{ft} .10 \mathrm{in}$. at breast height-equal to a diameter of nearly $5 \mathrm{ft}$. It is interesting to note that this same tree is mentioned by Henry John Elwes in "Trees of Great Britain and Ireland", when the measurement taken by him in 1904 was recorded as $100 \mathrm{ft}$. in height, $9 \frac{1}{2} \mathrm{ft}$. in girth, with a diameter of $37 \mathrm{in}$.
Other examples of exceptional growth can be seen at Puck Pits in the New Forest, the magnificent avenue at Murthly Castle, and those at Taymount. When it is realized that such trees can be produced in about seventy years, the planting of Douglas firs should be widely encouraged.

A careful inquiry as to the commercial value to-day of an average tree of 70-80 years growth displays the following :

$$
\begin{aligned}
& \begin{array}{cccccc}
\text { Scots pine } & & & & & \text { Per tree } \\
\text { (1) } & \text { My Report } & \ldots & \ldots & \ldots & 278.0 d .
\end{array} \\
& \text { (2) Forestry Commission Report .. 208. 0d. } \\
& \text { Larch } \\
& \text { (1) My Report } \quad \text {. } \quad \ldots \quad \text {. } 37 s .6 d \text {. } \\
& \text { (2) Forestry Commission Report .. 33s. } 0 d \text {. }
\end{aligned}
$$

Average of the Douglas Ar at Haslemere

$$
\text { more than } £ 60 \text { s. }
$$

Henry John Elwes, than whom there was never a more zealous planter, did not display his usual enthusiasm on the subject of Douglas fir, but it is probable that he was influenced by the result of experiments in Scotland and in the cold hills of Gloucestershire, and also because the conditions forty-two years ago were so different from those which obtain to-day.

Experiments have shown, as previously pointed out, that this particular tree can only be successfully reared in certain areas and soils, and under more scientific planting than has been practised heretofore-a handicap always unavoidable with the introduction of a tree the natural habitat of which belongs to a different country and climate.

A large quantity of cones are being collected from the Haslemere trees, which are producing good seed at a crucial moment, since the crop of Canadian seed is reported to have failed.

The vital importance of a sufficient reserve of timber supplies has been peculiarly forced upon us by a demand such as has never before been experienced in the history of Great Britain. Our woodlands, once our pride and glory, are being denuded, not only of their beauty, but also of their value, and it is therefore a national duty, incumbent upon every one of us, without delay, to pursue those measures necessary to repair the loss of such a vital necessity to the existence of the country. Among those other efforts which should be made, the planting of Douglas fir should take a prominent place.

\section{GEOLOGY IN POST-WAR PLANNING}

\section{By Prof. P. G. H. BOSWELL, F.R.S.}

GROM the reply of the Secretary of State for War I to a question recently asked in the House of Commons, it seems that we have now arrived, in the fourth year of war, at the stage reached after the Gallipoli campaign of the War of 1914-18 ; for history is repeating itself in that water-divining in the Army is to be replaced by scientific methods of discovery (see Nature, January 30 , p. 118). A further, although belated, encouragement to geologists in their efforts to overcome public neglect of the science has just come from an American correspondent in the shape of news that the U.S. Geological Survey is actively co-operating in the preparation of maps for the North African campaign, and that geological staff officers are accompanying some of the U.S. task forces. If we do not relax our efforts it is 
perhaps not too much to hope that the staff of two geologists at present attached to the British Army may be increased to the total of five who were in commission in 1918-or perhaps even to the much larger number which alone would be adequate.

There are many who, like the writer, believe that the remedy for the present failure to utilize geology to the full is to be found only in broadening the basis of education, and that the cure will take a generation to be effected; but this conviction is no reason for failing to press the claim of geology as one of the primary considerations in national planning. There is still time to ensure that geologists shall take an active part in assisting with schemes of reconstruction. Their help is indispensable for the success of postwar planning, for geological knowledge is necessary whether the question is one concerned with raw materials, with the location of industries, with the allocation of land for particular purposes, or with water-supply and drainage. Certain of the large industrial organizations have wisely begun preparing for post-war conditions and demands (so far, of course, as current restrictions permit), and, in doing so, are seeking geological advice. Others will doubtless awake to the necessity for early preparation so soon as the Government announces its planning policy.

Local authorities responsible for town and country planning schemes may in some cases be unaware of geological repercussions, but if they are being advised by Prof. Patrick Abercrombie, such contacts are not likely to be ignored. At the moment, however, local authorities are also awaiting clarification of the Government's attitude towards the recommendations of the Scott and Uthwatt Committees and the Royal Commission on the Distribution of the Industrial Population (the Barlow Report). These authorities, through their planning committees, will probably have the responsibility within the framework of the Government policy, and subject to the approval of the appropriate Minister or Ministers, of determining how particular areas can best be utilized for the four respective needs of agriculture, other industries, housing and open spaces, taking into account both existing conditions and future requirements. Since geology is the science of the earth, it has a fundamental, although perhaps indirect, effect on the character and quantity of food supply by way of soil control; but it bears more directly on questions of water-supply, health and housing of the community, and the location of the industries by means of which we contrive to exist.

It is well known, of course, that the adjustment of various interests is no easy task in any scheme of planning. The responsibility for decisions will rest with the Minister of Town and Country Planning, but he will need the best advice he can command when he is faced by the problem of reconciling the conflicting claims that will inevitably arise. In many cases difficulties will be found inherent in the actual claims, apart entirely from the problems raised by particular vested interests. For example, it almost seems to be labouring the obvious to emphasize that the suitability of land for the various purposes mentioned above depends on sub-surface geological characters which cannot be altered. The characters which render land suitable for residential purposes are those desirable also for the maintenance of underground water-supplies; but houses, factories and made-up roads constitute an effective mackintosh and thus divert the rainfall. Reservation of land for agriculture and water-supply need not, it is true, lead to conflict, but scientific advice should be taken in every case. Also, the exploitation of the raw materials necessary for reconstruction must be on a huge scale; and here we should have in mind not so much the winning of coal and mineral ores, important as they are, as such common rocks as sand, gravel and stone for concrete and road metal, limestone and clay for cement, brickmaking, and chemical industries. These will require the reservation, at least for many years, of tracts of country which cannot be otherwise allocated, for example, for housing or open spaces. During the past fifty years, the tendency has been towards the abandonment of the small sand and gravel pits, village brickyards and lime-kilns worked by manual labour, and towards the concentration of these industries as large mechanized undertakings, frequently on the fringe of the conurbations. Already, in anticipation of the needs of rebuilding damaged cities and the probable expansion of their housing estates, interested parties are endeavouring to get a lien on resources of raw materials not too far distant from the markets. Further, the provision of water for public supplies and the ever-increasing needs of industry are often difficult to reconcile. Certain large works individually now require as much water. as a big town or city of 100,000 to 200,000 inhabitants : if the supplies are derived from underground sources, considerable areas of the country are thus preoccupied. The development of new industries after the War of 1914-18 made heavy demands upon water-supply and in many districts upset the balance as between public and private requirements. The rayon industry with its high consumption of water is, we hope, but the forerunner of a vigorous plastics industry in Britain. Those types of plastics which will form an outlet for coal will obviously be favourably regarded, and in this connexion it is worthy of note that the raw materials, coal, limestone and water, are all abundant in Britain. But they are not all abundant in the same place, where power also must be available on a considerable scale : two of them can be economically transported, but not the third, which would involve great capital expenditure.

Much of the water required in industry is used for washing and cooling purposes, and is released again as effluent, often but little polluted, but sometimes unusable until naturally or artificially purified. The manner and ease of its disposal so as to do least harm to the community are dependent, like the location of cemeteries, sewage works and drainage generally, on the geological character of the terrain. In order to bring the partially or completely purified effluent back into service, a dual water-supply system is called for, but such a course is at present open to objection because of cost and public prejudice. No doubt many are familiar with the only too common misfortunes which have arisen from billeting, the establishment of camps, and the búilding of houses and works before the existence of the essential watersupply has been assured. Consultants are frequently asked to find substantial supplies of water, not only for growing communities, but also for works which were established before adequate resources were proved or where account had not been taken of the demands of expanding activity. Such lack of foresight frequently accompanies haphazard growth and is perhaps only to be expected in the absence of schemes of planning.

The effectiveness of wide-scale action during planning in the matter of allocating water-supplies is at present seriously hampered by the absence of nationa] 
control. In accordance with the legal canon that there is no property in underground water, registration of wells and boreholes in Great Britain is not compulsory. Until the recommendations of the Ministry of Health Advisory Committees of 1925 and 1938 are implemented by legislation-perhaps by a system of licensing to bore (as for petroleum) and safeguarding from pollution-no protection of public or private water-supplies, either as regards quantity or quality, can be assured.

Before industrial works are located, consideration is usually given to the questions of proximity to markets, transport facilities, availability of power, and the sources of raw materials; possibly also to the local labour market and the matter of suitable housing. To these primary considerations there should always be added those of water-supply and drainage.

The requirements of various industries for other raw materials besides water are also liable to be mutually interfering: therefore, in order fairly to reconcile the competing claims, some amount of give. and-take or rationing may become necessary in particular areas. The earlier and almost unrestricted practice of "first come, first served", defensible as it may have been before districts became congested, has led to the situation which called for the setting up of many commissions and committees of incuiry, and is now less likely to commend itself to local authorities, however influenced they may be by prospects of increased income from rates.

It is not beyond the bounds of possibility that any plans for the future will have to take account of underground accommodation and storage. However high our ideals may be for post-war international relationships, common prudence may cause politicians to make provision to meet a possible breakdown. Geological knowledge in planning is therefore indispensable if we are to be ready, albeit unwillingly, to revert to a trogloditic phase.

Many of the mistakes of the war planning, which have led to great delays, loss of labour and wear and tear of valuable machinery, might have been avoided if geological advice had been sought; and the adverse effects could have been minimized if the cooperation between various Government departments had been more effective : that is, to use Sir Stafford Cripps's words, if there had been geological advice "at the highest level", the requirements of various war-time activities might have been more satisfactorily adjusted. The recent remark of Sir Philip Joubert at the Conference on the Planning of Science arranged by the Association of Scientific Workers should always be kept in mind: "If ... the scientist never initiates any action and always waits to be asked a question ... he will lose half his value". Therefore, one may feel the more encouraged in urging (especially at a time when 'science' seems in many quarters to be synonymous with physics) how important it is that a scientific advisory committee should be set up to assist the Minister of Town and Country Planning at the highest level. Such a committee, concerned with the strategy of planning, should include at least one geologist. The activities of the central planning authority will inevitably impinge on those of several Government departments. For that reason and in order to simplify the problem of co-operation, the geologist invited to serve should not be officially connected with any Government department. His independence would be a source of strength.

\section{SOME CZECHOSLOVAK CONTRIBUTIONS TO GENETICS} (1866-1938)

\section{By Dr. GERALD DRUCE}

A LTHOUGH the breeding and crossing of plants $A$ and animals has been in vogue for a long time, the scientific control and study of the processes belong to the twentieth century; even Mendel's early pioneer work was not appreciated for almost half a century.

Born of poor parents in 1822, Gregor J. Mendel showed promise at school and was admitted to the Augustinian monastery at Brno (Brünn) in Moravia. His scientific work began when he was sent, in 1851 , to Vienna to study the natural sciences, for which he showed an aptitude. At Vienna he wrote two notes dealing with Scopolia margaritalis (1853) and Bruchus pisi (1854). Returning to Brno he taught science at the secondary school and spent eight years in a study of the crossing of peas. This work virtually ceased when he became prelate in 1868 , and his afterlife was clouded by a bitter controversy with the secular authorities over the taxation of the monastic. domains.

Mendel knew of Darwin's theory of evolution, but did not entirely accept it. Darwin never knew of Mendel's work, which was published in the local natural history society's journal'. Among the very few biologists who knew of Mendel's work was the German, Nägeli, and he failed to recognize its significance. Mendel himself was depressed by the fact that his discovery was ignored. Only two minor references were made to it in his lifetime ${ }^{2}$, and not until 1900 was its importance realized by several men of science simultaneously ${ }^{3}$.

Mendel's experiments were carried out in a small corner of the monastery grounds where, over a period of years, he sowed his hybrid peas. He was aware of the difficulties in experimenting with hybrids, though nothing was then known of the number of possible types of offspring from any cross. No control had previously been made of separate genera. tions nor were any reliable statistical data available, though crossing for improving stock had been practised in Bohemia, for example, at the Kladruby stud where horses had been bred since 1563. Also before Mendel's time local varieties of apples were obtained by selective crossing.

Mendel used peas because they possessed constant distinguishing characters and the hybrids were easily protected from cross-pollination. Moreover, the tedious process of artificial pollination in these plants did give good crops. A consideration of the results obtained over a number of generations are expressed in what are termed the Mendelian laws. Mendel expressed his conclusions in the following way: "In hybrids the relation of each pair of different characters (e.g., tall or dwarf, smooth or wrinkled) is independent of other differences in the original stocks"; and "the constant characters that appear in several varieties can be obtained by repeated artificial pollination in all possible associations according to mathematical rules".

He recognized that all the characters of a plant or animal must be transmitted to the offspring through the germ cells (in plants through the pollen grains and the ovules). To this he added the conception of alternative unit characters present in the 